\title{
Summertime tropospheric ozone over China simulated with a regional chemical transport model \\ 2. Source contributions and budget
}

Jianzhong Ma and Xiuji Zhou

Chinese Academy of Meteorological Sciences, Beijing, People's Republic of China

\author{
Didier Hauglustaine ${ }^{1}$ \\ Service d'Aéronomie du Centre National de la Recherche Scientifique, Paris, France \\ Received 4 October 2001; revised 26 January 2002; accepted 5 March 2002; published 16 November 2002.
}

[1] A regional three-dimensional chemical transport model is used to simulate the contributions of various sources to the $\mathrm{NO}_{\mathrm{x}}$ and $\mathrm{O}_{3}$ distributions in the troposphere over China during a summertime period. $\mathrm{O}_{3}$ tracers are added in the model to simulate the distribution of $\mathrm{O}_{3}$ that originates from stratosphere-troposphere exchange (STE), lateral boundary import (LBI) and in situ photochemistry via NO, respectively. Tracers for reactive nitrogen species are further incorporated into the model to simulate the distributions of $\mathrm{NO}_{\mathrm{x}}$ that originate from surface emissions, aviation, lightning, STE and LBI, respectively. Meanwhile, the $\mathrm{O}_{3}$ formed by chemical reactions via the NO tracer originating from these sources is also tagged. The model results indicate that surface emissions are the dominant contributor to the $\mathrm{NO}_{\mathrm{x}}$ and hence $\mathrm{O}_{3}$ concentrations in the polluted boundary layer of eastern China. At higher altitudes the $\mathrm{O}_{3}$ produced via surfaceemitted $\mathrm{NO}_{\mathrm{x}}$ accounts for $10-20 \%$ of the $\mathrm{O}_{3}$ concentrations over these polluted regions. The impact of aircraft $\mathrm{NO}_{\mathrm{x}}$ emissions on tropospheric $\mathrm{O}_{3}$ over China is small, contributing up to $2 \%$ of the $\mathrm{O}_{3}$ concentrations at cruise altitudes. The net $\mathrm{O}_{3}$ production via surface-emitted $\mathrm{NO}_{\mathrm{x}}$ over the region is estimated to be $132 \mathrm{Gg} \mathrm{d}^{-1}$ in the boundary layer and $33 \mathrm{Gg} \mathrm{d}^{-1}$ in the free troposphere. Because there is much more $\mathrm{O}_{3}$ transported into than out of the region and high relative humidity, in situ photochemistry acts as a sink for $\mathrm{O}_{3}$ in the troposphere over the region. INDEX TERMS: 0365 Atmospheric Composition and Structure: Troposphere-composition and chemistry; 0368 Atmospheric Composition and Structure: Troposphere - constituent transport and chemistry; 0322 Atmospheric Composition and Structure: Constituent sources and sinks; 0345 Atmospheric Composition and Structure: Pollution—urban and regional (0305); KEYWORDS: tropospheric ozone, modeling, nitrogen oxides, tagging procedure, ozone budget, China

Citation: Ma, J., X. Zhou, and D. Hauglustaine, Summertime tropospheric ozone over China simulated with a regional chemical transport model, 2, Source contributions and budget, J. Geophys. Res., 107(D22), 4612, doi:10.1029/2001JD001355, 2002.

\section{Introduction}

[2] In a companion paper [Ma et al., 2002b], we described a regional three-dimensional chemical transport model for the simulation of tropospheric ozone chemistry over China, and evaluated the model by comparing simulated distributions of tropospheric ozone $\left(\mathrm{O}_{3}\right)$ and its precursors with available observations and other model results for summertime. In this paper, we use the model to analyze the factors that control tropospheric ozone over China during the summertime period and quantify the contributions of various sources to the concentrations of nitrogen oxides $\left(\mathrm{NO}_{\mathrm{x}}=\mathrm{NO}+\right.$ $\mathrm{NO}_{2}$ ) and $\mathrm{O}_{3}$ in the troposphere over the region.

\footnotetext{
${ }^{1}$ Also at Laboratoire des Sciences du Climate et de l'Environnement, Gif-sur-Yvette, France.

Copyright 2002 by the American Geophysical Union.
} 0148-0227/02/2001JD001355
[3] The source turning on and off method has been widely used in model studies of tropospheric $\mathrm{O}_{3}$, particularly its perturbation by human activities. The method is very efficient in evaluate the impact of current (or future) pollutant emissions on the pristine (or present) "background" atmosphere. However, the turning on and off method is not so efficient in the study of various processes in a specific atmosphere. For instance, if one investigates the significance of stratospheric $\mathrm{O}_{3}$ intrusions to the source of tropospheric $\mathrm{O}_{3}$ using turning on and off method, it would be difficult to quantify the relevant contribution, since the concept of the atmosphere with stratospheric $\mathrm{O}_{3}$ source being turned off is not clear. For this case, the tagging (or tracing) procedure provides a different and more efficient measure of the relative importance of different sources to tropospheric $\mathrm{NO}_{x}$ and $\mathrm{O}_{3}$ levels, as the chemical characteristic of the simulated atmosphere keeps the same while adding a tracer. Lamarque et al. [1996] 
estimated the relative contributions of the different $\mathrm{NO}_{\mathrm{x}}$ sources in the troposphere. Wang et al. [1998] quantified the contributions to tropospheric $\mathrm{O}_{3}$ concentrations from production in the stratosphere, the upper troposphere, the polluted continental boundary layer, as well as the middle troposphere and the marine boundary layer. Horowitz and Jacob [1999] evaluated the global impact of fossil fuel combustion on tropospheric $\mathrm{NO}_{\mathrm{x}}$, with a focus on the importance of emissions from United States and China. Roelofs and Lelieveld [1997], Kentarchos et al. [1999] and Lelieveld and Dentener [2000] studied the effect of stratosphere-troposphere exchange (STE) on tropospheric $\mathrm{O}_{3}$ levels in different regions.

[4] In the present study, we investigate the contributions of various sources to the $\mathrm{NO}_{x}$ and $\mathrm{O}_{3}$ concentrations in the troposphere over China using a regional chemical model with the tagging procedure incorporated. First, we trace the $\mathrm{O}_{3}$ that originate from STE, lateral boundary import (LBI), and in situ photochemistry via NO (CHEM). Then, we trace the reactive nitrogen species from the individual source of surface emission, aviation, lightning, STE and LBI. At the same time, the $\mathrm{O}_{3}$ formed by chemical reactions via the different NO tracers from these sources are also traced. Finally, the budget of tropospheric $\mathrm{O}_{3}$ over the region is analyzed. As in the companion paper [Ma et al., 2002b], our simulations have been performed for a summertime period July 1-15 of 1995, and the results of the last six days are analyzed considering that the initial conditions of chemical species can decade away after a 9-day simulation.

\section{Ozone Transported to and Formed Within the Region}

[5] From a global point of view, tropospheric $\mathrm{O}_{3}$ arises from two processes: stratosphere-troposphere exchange (STE), and in situ photochemical production from the oxidation of hydrocarbons and $\mathrm{CO}$ in the presence of $\mathrm{NO}_{\mathrm{x}}$ (CHEM). Ozone is removed from the troposphere by in situ chemistry and by uptake at the Earth's surface. Tropospheric $\mathrm{O}_{3}$ has a lifetime of several weeks, and can be transported on a global scale. Therefore, from a regional point of view, tropospheric $\mathrm{O}_{3}$ over a specific region may also come from lateral boundary import (LBI). We added an $\mathrm{O}_{3}$ tracer, $\mathrm{O}_{3}^{\mathrm{T}}$, in the model to investigate these ozone sources over China for the simulated period. The tracer $\mathrm{O}_{3}^{\mathrm{T}}$, which is assigned to come from a specific source, has the same chemical and physical removal processes as "regular" $\mathrm{O}_{3}$. Only one $\mathrm{O}_{3}$ source was traced for each model simulation, although theoretically several tracers could be added to account for different sources in a model simulation. We tagged the STE $\mathrm{O}_{3}^{\mathrm{T}}$ by imposing the same tropopause concentration as for regular $\mathrm{O}_{3}$, the LBI $\mathrm{O}_{3}^{\mathrm{T}}$ by assuming the same lateral boundary condition as for regular $\mathrm{O}_{3}$, and the CHEM $\mathrm{O}_{3}^{\mathrm{T}}$ by using chemical reactions via NO, while the otherwise sources were switched off. For instance, the vertical upper boundaries for the LBI and CHEM $\mathrm{O}_{3}^{\mathrm{T}}$ and the lateral boundaries for the STE and CHEM $\mathrm{O}_{3}^{T}$ were assumed to be zero. In this way, each source of the regional $\mathrm{O}_{3}$ was taken into account and not calculated repeatedly.

[6] From a dynamic point of view, $\mathrm{O}_{3}$ in the troposphere has a short lifetime against the reaction

$$
\mathrm{NO}+\mathrm{O}_{3} \rightarrow \mathrm{NO}_{2}+\mathrm{O}_{2}
$$

However, $\mathrm{O}_{3}$ is reformed rapidly in sunlight by the reactions

$$
\begin{aligned}
& \mathrm{NO}_{2}+\mathrm{h} \nu(\lambda<420 \mathrm{~nm}) \rightarrow \mathrm{NO}+\mathrm{O}^{3} \mathrm{P} \\
& \mathrm{O}^{3} \mathrm{P}+\mathrm{O}_{2}+\mathrm{M} \rightarrow \mathrm{O}_{3}+\mathrm{M}
\end{aligned}
$$

Reactions (R1)-(R3) represents a null cycle for ozone production and loss since no change in the $\mathrm{O}_{3}$ abundance results at steady state. Therefore, the reaction (R1) is not considered as a loss of the tracer $\mathrm{O}_{3}^{\mathrm{T}}$. This treatment may under estimate the loss of $\mathrm{O}_{3}$ tracers at night especially when $\mathrm{NO}_{\mathrm{x}}$ levels are relatively high. The limitation of the tagging technique used will be discussed below. The photodissociation of $\mathrm{O}_{3}$ molecules at ultraviolet wavelengths

$$
\mathrm{O}_{3}+\mathrm{h} \nu(\lambda<320 \mathrm{~nm}) \rightarrow \mathrm{O}\left({ }^{1} \mathrm{D}\right)+\mathrm{O}_{2}
$$

followed by the reaction with water vapor

$$
\mathrm{O}\left({ }^{1} \mathrm{D}\right)+\mathrm{H}_{2} \mathrm{O} \rightarrow 2 \mathrm{OH}
$$

act as a sink for $\mathrm{O}_{3}$. In addition, ozone loss through the $\mathrm{HO}_{\mathrm{x}}$ $\left(=\mathrm{OH}+\mathrm{HO}_{2}\right)$ catalytic cycle

$$
\begin{gathered}
\mathrm{HO}_{2}+\mathrm{O}_{3} \rightarrow \mathrm{OH}+2 \mathrm{O}_{2} \\
\mathrm{OH}+\mathrm{O}_{3} \rightarrow \mathrm{HO}_{2}+\mathrm{O}_{2}
\end{gathered}
$$

and addition reaction with olefins (alkenes), OL, are included for the loss of the tracer $\mathrm{O}_{3}^{\mathrm{T}}$.

$$
\mathrm{OL}+\mathrm{O}_{3} \rightarrow \text { aldehyde }+ \text { radicals }
$$

Other loss processes involved by odd oxygen, for instance,

$$
\mathrm{HO}+\mathrm{NO}_{2}+\mathrm{M} \rightarrow \mathrm{HNO}_{3}+\mathrm{M}
$$

are not taken into account in the loss term for the STE $\mathrm{O}_{3}^{\mathrm{T}}$ and LBI $\mathrm{O}_{3}^{\mathrm{T}}$, since these reactions are much less important than the reactions (R4)-(R7). $\mathrm{NO}_{2}$, as an odd oxygen species, may attribute either $\mathrm{STE} \mathrm{O}_{3}^{\mathrm{T}}$, or LBI $\mathrm{O}_{3}^{\mathrm{T}}$, or CHEM $\mathrm{O}_{3}^{\mathrm{T}}$, and it is not traced in the present study. In order to avoid repeated calculations, only for CHEM $\mathrm{O}_{3}^{\mathrm{T}}$ is the reaction (R9) taken into account, considering that this reaction is relatively import in the polluted regions where $\mathrm{NO}_{\mathrm{x}}$ levels are high.

[7] $\mathrm{O}_{3}$ is dynamically formed via the reaction (R3) in the troposphere, and the reaction (R2) provides a main source of odd oxygen atom $\mathrm{O}\left({ }^{3} \mathrm{P}\right)$. However, as discussed above, the production of $\mathrm{O}_{3}$ via the reaction (R2)-(R3) is balanced by its destruction via the reaction (R1). On the other hand, peroxy radicals $\mathrm{HO}_{2}$ and $\mathrm{RO}_{2}$ (where $\mathrm{R}$ refers to organic groupings), which are produced through the oxidation of 

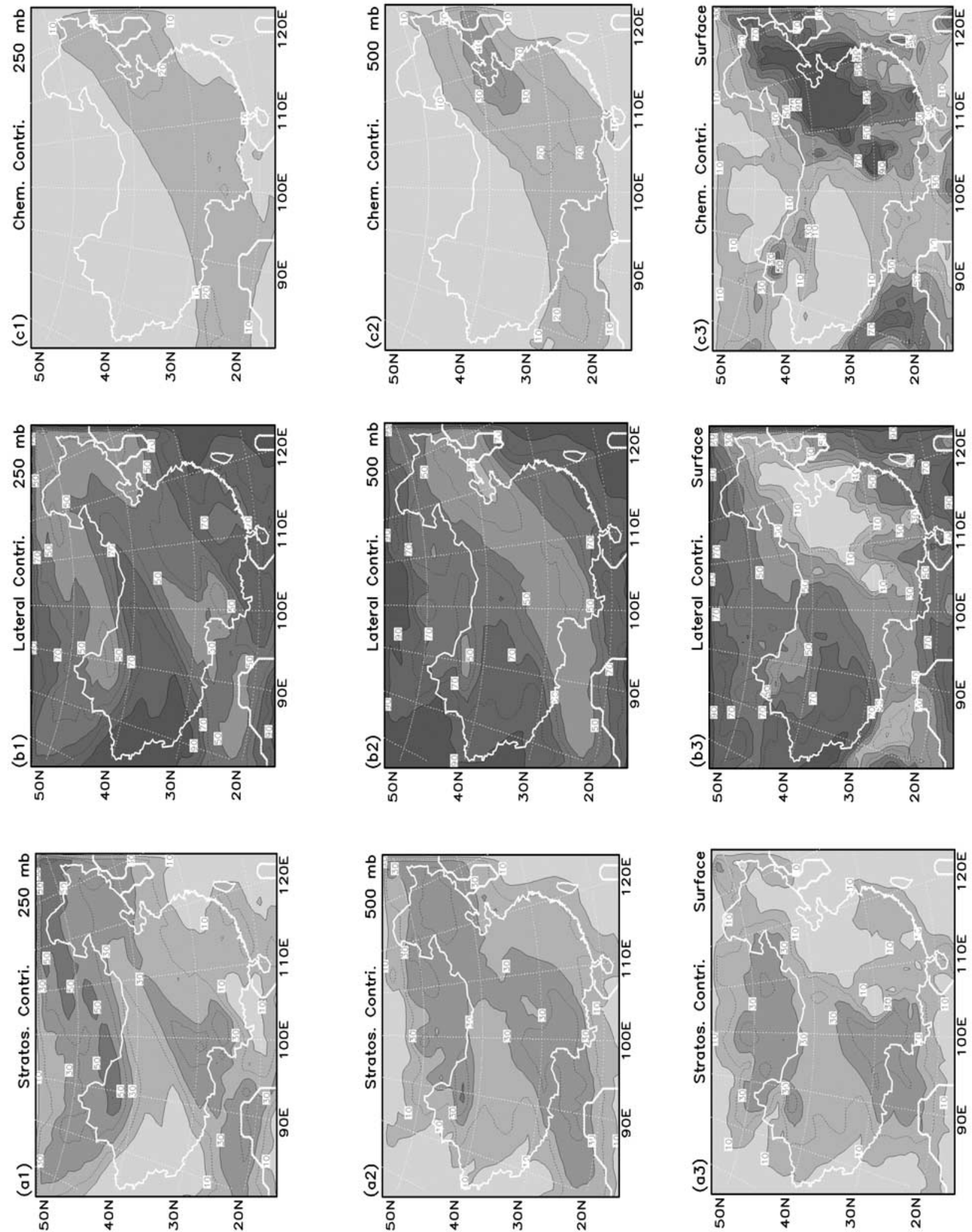

Figure 1. Calculated percent contributions to $\mathrm{O}_{3}$ concentrations at the surface (1), 500 mbar (2) and $250 \mathrm{mbar}(3)$ from stratospheric $\mathrm{O}_{3}$ intrusion (a), lateral $\mathrm{O}_{3}$ import (b), and chemical production within the region (c) for July $10-15$, 1995 . Contour levels are 10, 30, 50, 70 and 90 for solid lines, and 20, 40, 60 and 80 for dashed lines. 

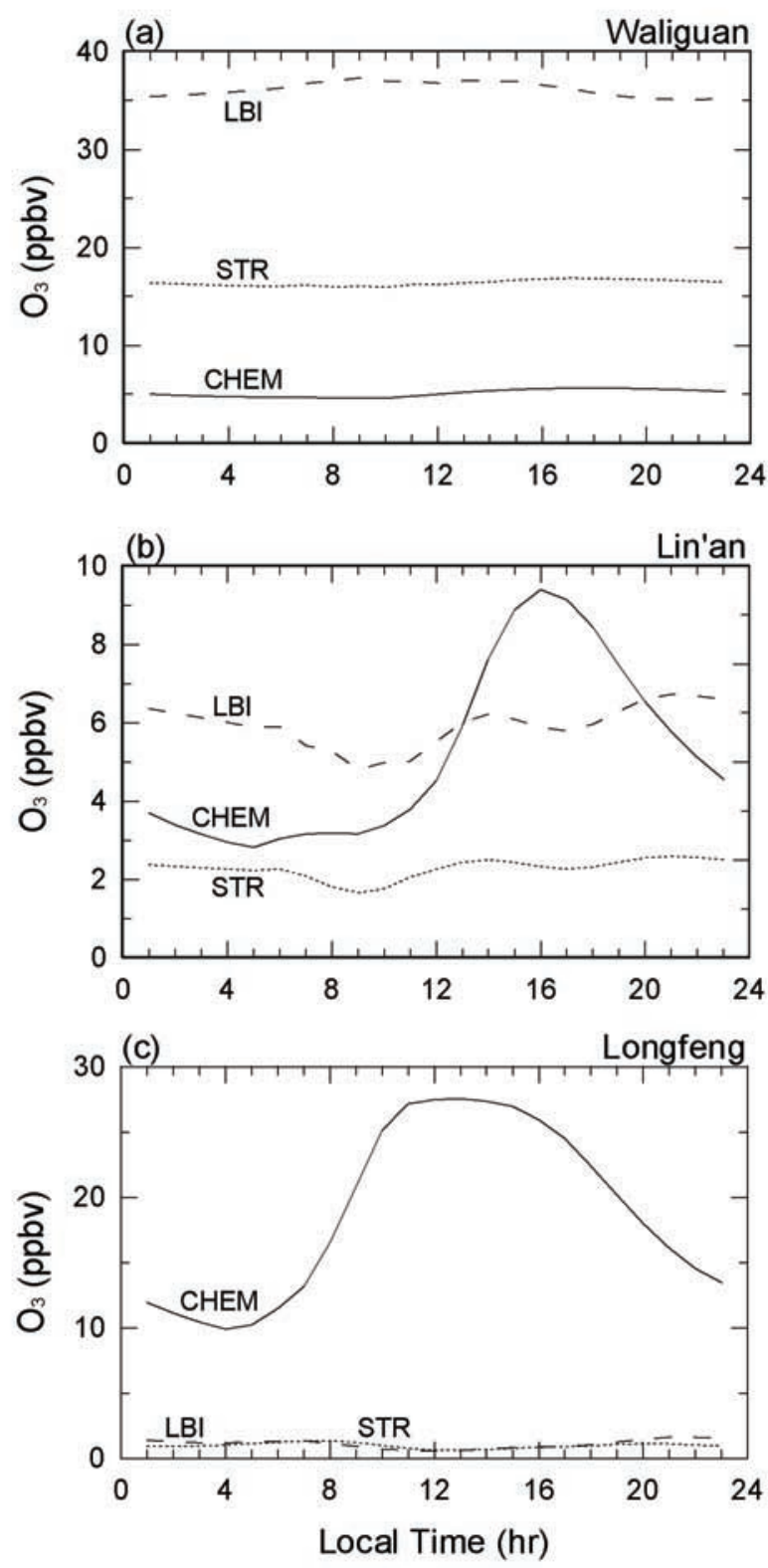

Figure 2. Calculated source attribution of mean diurnal cycles of surface $\mathrm{O}_{3}$ over the period July $10-15,1995$ at the WMO/GAW stations of Waliguan (a), Lin'an (b) and Longfeng (c). Dotted lines stand for stratospheric $\mathrm{O}_{3}$ intrusion (STE), dashed lines for lateral $\mathrm{O}_{3}$ import (LBI), and solid lines for chemical production within the region (CHEM). See Table 3 and Figure 6 of Ma et al. [2002b] for an introduction of the three $\mathrm{WMO} / \mathrm{GAW}$ stations in China.

$\mathrm{CO}$ and hydrocarbons, can also efficiently oxidize NO to $\mathrm{NO}_{2}$ by reactions

$$
\begin{gathered}
\mathrm{HO}_{2}+\mathrm{NO} \rightarrow \mathrm{OH}+\mathrm{NO}_{2} \\
\mathrm{RO}_{2}+\mathrm{NO} \rightarrow \mathrm{RO}+\mathrm{NO}_{2}
\end{gathered}
$$

Thus, the reaction (R10) and (R11) are considered as the rate-determining steps for the effective formation of the $\mathrm{CHEM} \mathrm{O}_{3}^{\mathrm{T}}$ in the present study. The loss term of the CHEM
$\mathrm{O}_{3}^{\mathrm{T}}$ is the same as that of the STE $\mathrm{O}_{3}^{\mathrm{T}}$ and LBI $\mathrm{O}_{3}^{\mathrm{T}}$, except that the reaction (R9) is included for the CHEM $\mathrm{O}_{3}^{\mathrm{T}}$. So far, one can see that factually it is odd oxygen, $\mathrm{O}_{\mathrm{x}}\left(\mathrm{O}_{\mathrm{x}}=\mathrm{O}_{3}+\mathrm{O}\left({ }^{3} \mathrm{P}\right)+\right.$ $\left.\mathrm{O}\left({ }^{1} \mathrm{D}\right)+\mathrm{NO}_{2}\right)$, instead of $\mathrm{O}_{3}$ molecule it self, that has been traced as $\mathrm{STE} \mathrm{O}_{3}^{\mathrm{T}} \mathrm{LBI} \mathrm{O}_{3}^{\mathrm{T}}$, and CHEM O $\mathrm{O}_{3}^{\mathrm{T}}$, respectively, in the present study.

[8] After 15-days integration, the sum in the tropospheric burden of STE, $\mathrm{LBI}$ and $\mathrm{CHEM} \mathrm{O}_{3}$ tracers was calculated to be $10 \%$ more than the tropospheric burden of "regular" $\mathrm{O}_{3}$ $(13.8 \mathrm{Tg})$ over the region. The lack of additivity of the tagged tracers used cannot be due to the boundary conditions assumed, since the boundary conditions are additive for all the sources. It may come from inappropriate assumptions of what constitutes chemical loss of a tagged $\mathrm{O}_{3}$ tracer. It may also arise from the assumptions of what constitutes formation of a tagged $\mathrm{O}_{3}$ tracer. Therefore, it should be admitted that the tagging technique is at best approximate for $\mathrm{O}_{3}$, and that it provides an estimate of contributions with an error of approximately $10 \%$. Since odd oxygen is tagged in all the cases, it is expected that discrepancies will affect different tracers in the same direction, although the magnitude may be quite different. Hence, the deviation in the calculated relative contribution of a tracer to the regular $\mathrm{O}_{3}$ will be smaller than $10 \%$ with respect to its theoretical relative contribution.

[9] Figure 1 presents the calculated percent contributions of different $\mathrm{O}_{3}$ tracers to the $\mathrm{O}_{3}$ concentration at the surface, $500 \mathrm{mbar}$ and $250 \mathrm{mbar}$, respectively. The calculated concentrations in the absolute sense are not shown, as the similar distributions of $\mathrm{O}_{3}$ and other trace gases have been given in a companion paper [Ma et al., 2002b]. As shown in Figure 1, through STE stratospheric $\mathrm{O}_{3}$ contributes considerably to the $\mathrm{O}_{3}$ concentration in the troposphere, even down to the surface over some remote areas. STE is a dominant source of $\mathrm{O}_{3}$ in the upper troposphere of most northern parts of the model domain. It is noted that to the south of the Tibetan plateau, where the latitude is lower $\left(20-30^{\circ} \mathrm{N}\right)$, the signature of stratospheric $\mathrm{O}_{3}$ can also be found with a contribution of $30-40 \%$, due to strong deep convection. Lelieveld and Dentener [2000] also showed that STE significantly contributes to $\mathrm{O}_{3}$ in regions where the photochemistry is quiescent. LBI contributes significantly to tropospheric $\mathrm{O}_{3}$ over the region, especially in northwestern and southeastern parts of the region. These imported $\mathrm{O}_{3}$ can originally come from both STE and photochemical formation in the troposphere outside the region, and their attribution can be quantified with a global chemical transport model. The contribution of photochemistry occurring within the region to the $\mathrm{O}_{3}$ concentration is dominant in the polluted boundary layer and, in the free troposphere, it is still considerable (20$40 \%$ ) in downstream regions of polluted sources. In addition to eastern China, India looks like an important polluting source for the region that cannot be neglected.

[10] Figure 2 shows calculated source attribution of mean diurnal cycles of surface $\mathrm{O}_{3}$ at the three WMO/GAW stations in China (the reader is referred to $M a$ et al., [2002b] for a description of these three WMO/GAW stations in China). There is no significant daily variation in the contribution from CHEM at the Waliguan station. The contribution to the $\mathrm{O}_{3}$ concentration from LBI, STE and CHEM is about 36,16 , and 5 ppbv, respectively. So ozone at Waliguan is dynamically controlled. At the Lin'an station, the daily variation in the source contribution of CHEM is 

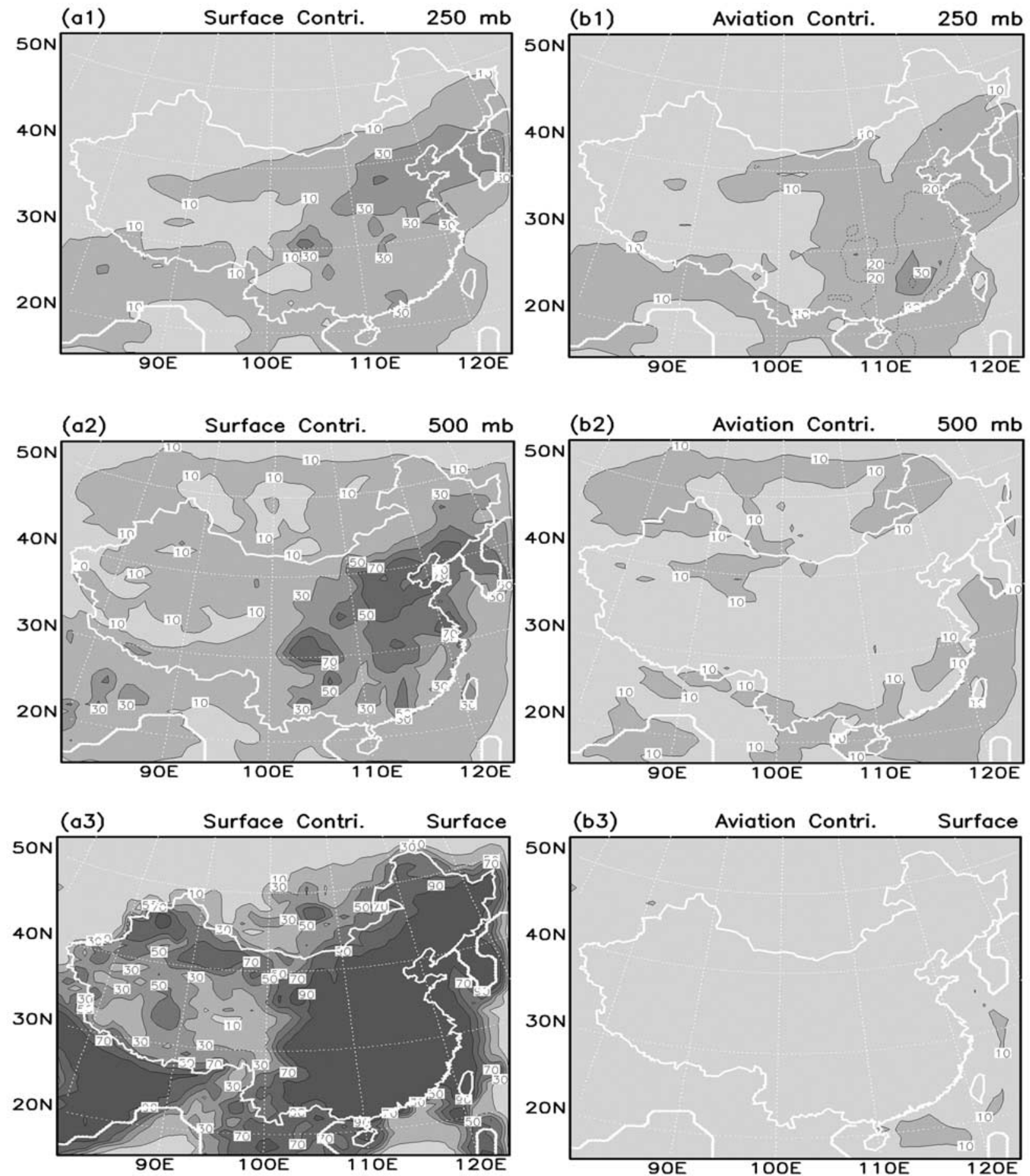

Figure 3. Calculated percent contributions to $\mathrm{NO}_{\mathrm{x}}$ concentrations at the surface (1), 500 mbar (2) and 250 mbar (3) from various reactive nitrogen sources including surface emission (a), aviation (b), lightning (c), stratospheric intrusion (d), and lateral import (e) for July 10-15, 1995. Contour levels are 10, 30, 50, 70 and 90 for solid lines, and 20, 40, 60 and 80 for dashed lines.

considerable, indicating that local photochemistry is active. The contribution of LBI is comparable to and at night even larger than the contribution of CHEM. At the Longfeng station, CHEM plays a predominant factor controlling the surface $\mathrm{O}_{3}$ as well as its diurnal variation, while the small effect of STE and LBI is simulated. The simulated daily variation in surface $\mathrm{O}_{3}$ is approximately three times larger at the Longfeng station than at the Lin'an station. While high levels of $\mathrm{CHEM} \mathrm{O}_{3}$ during the daytime indicate very active photochemistry occurring locally, high levels of $\mathrm{CHEM} \mathrm{O}_{3}$ 

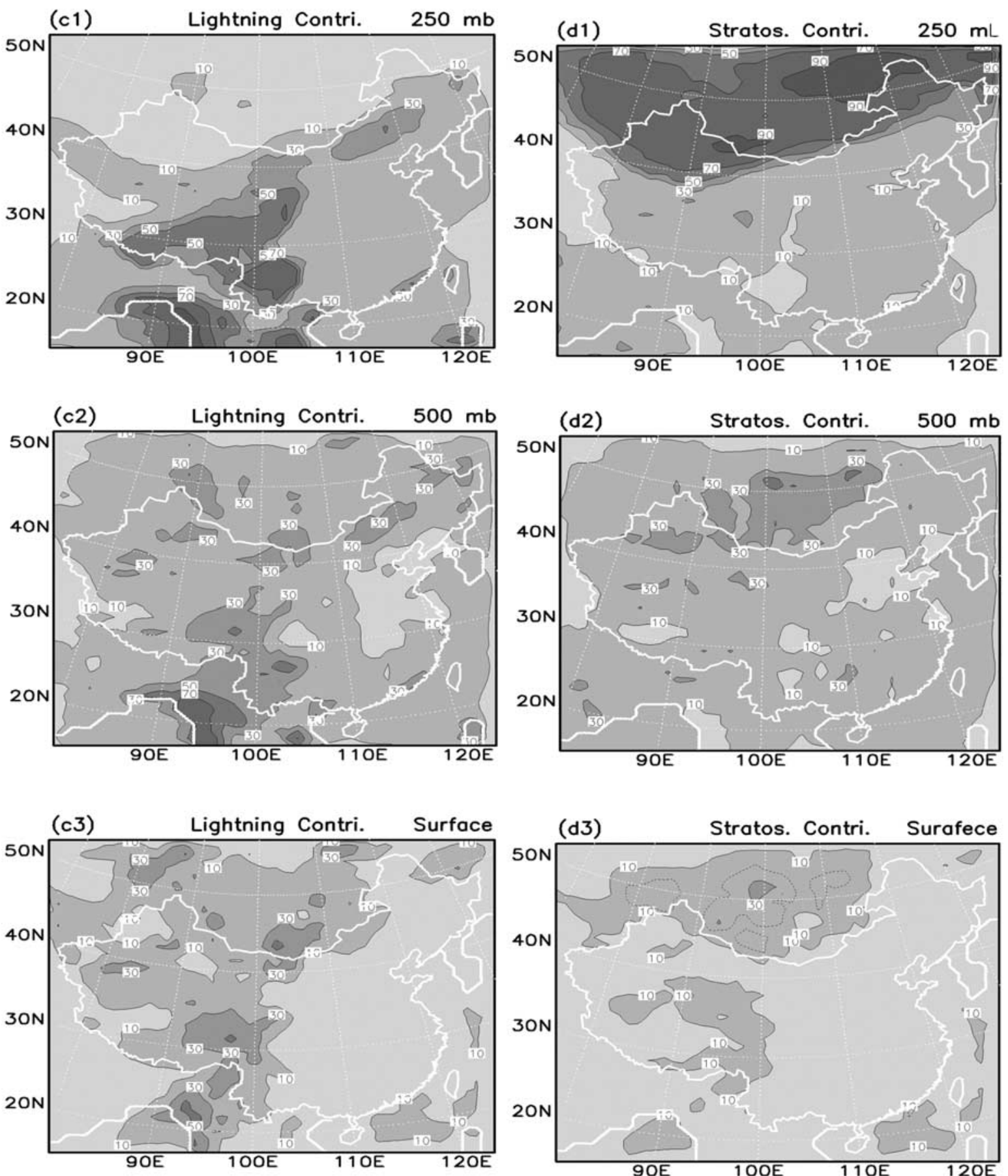

Figure 3. (continued)

at the nighttime may implicate high ozone formation in a large scale, especially its upstream regions.

\section{Ozone Formed Within the Region via Various Reactive Nitrogen Sources}

[11] We have shown in the above section that chemistry can significantly affect the $\mathrm{O}_{3}$ level in the troposphere over the region. In this section, we investigate the source attribution of photochemically produced $\mathrm{O}_{3}$ by tracing nitrogen-containing species from various sources, with more concern about the perturbation of tropospheric $\mathrm{O}_{3}$ by human activities such as fossil fuel composition and biomass burning. We tagged reactive nitrogen $\left(\mathrm{NO}_{\mathrm{y}}=\mathrm{NO}+\right.$ $\mathrm{NO}_{2}+\mathrm{NO}_{3}+\mathrm{N}_{2} \mathrm{O}_{5}+\mathrm{HNO}_{4}+\mathrm{HNO}_{3}+\mathrm{PAN}$ ) from a specific source, including surface emission, aviation, lightning, STE and LBI, by adding tracers $\mathrm{N}^{\mathrm{T}} \mathrm{O}, \mathrm{N}^{\mathrm{T}} \mathrm{O}_{2}, \mathrm{~N}^{\mathrm{T}} \mathrm{O}_{3}$, $\mathrm{N}_{2}^{\mathrm{T}} \mathrm{O}_{5}, \mathrm{~N}^{\mathrm{T}} \mathrm{NO}_{5}, \mathrm{HN}^{\mathrm{T}} \mathrm{O}_{4}, \mathrm{HN}^{\mathrm{T}} \mathrm{O}_{3}$ and $\mathrm{PAN}^{\mathrm{T}}$ in the model. These tracers were assigned to have the same physical and chemical behavior as corresponding "regular" nitrogencontaining species in the model simulation. The reactions involving dinitrogen species $\mathrm{N}_{2}^{\mathrm{T}} \mathrm{O}_{5}$ and $\mathrm{N}^{\mathrm{T}} \mathrm{NO}_{5}$ were decomposed with the same procedure as used by Horowitz and Jacob [1999]. We also added a tracer, $\mathrm{O}_{3}^{\mathrm{T}}$, which was 

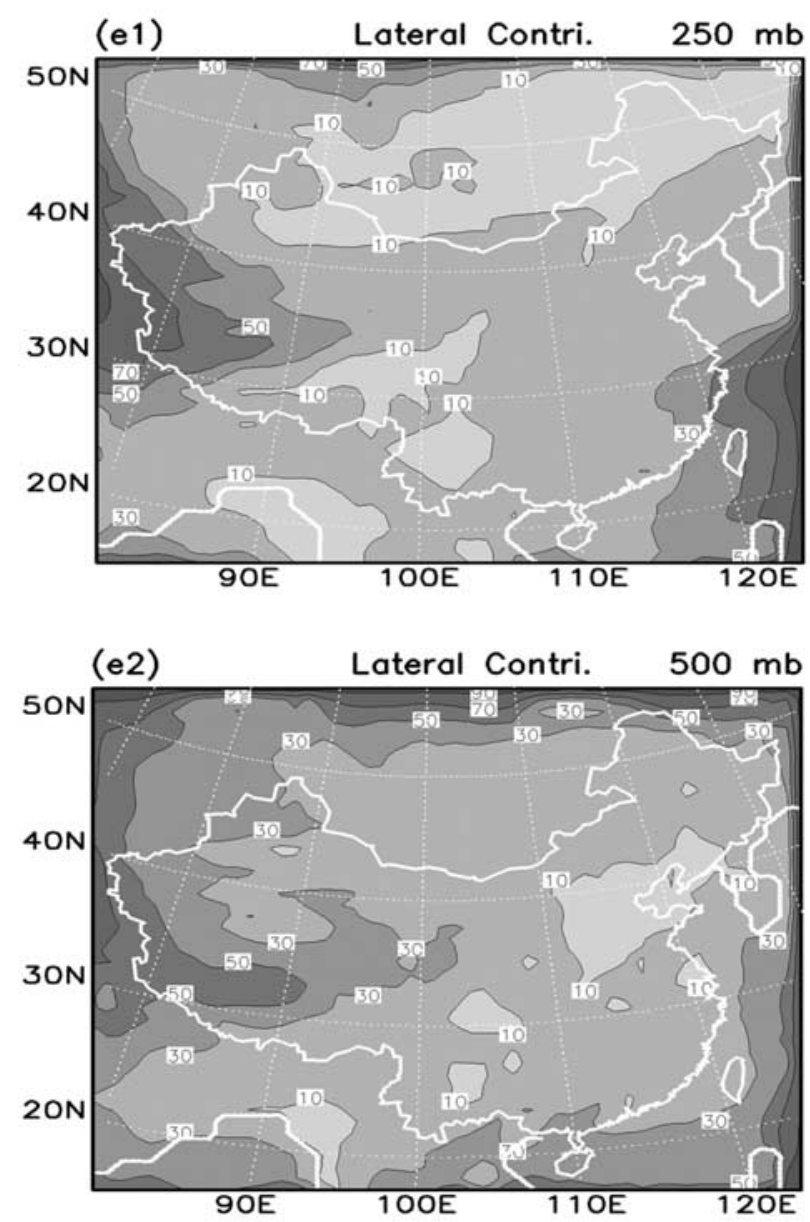

(e3)

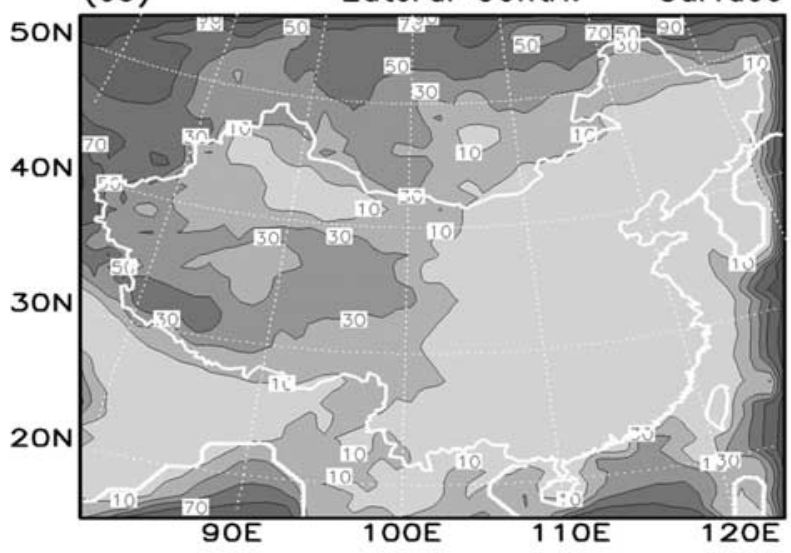

Figure 3. (continued)

assumed to be produced via $\mathrm{N}^{\mathrm{T}} \mathrm{O}$ traced above. The photochemical formation and loss of the tracer $\mathrm{O}_{3}^{\mathrm{T}}$ from tagged $\mathrm{N}$ species are identical to those of CHEM O $\mathrm{O}_{3}^{\mathrm{T}}$. Consequently, the $\mathrm{CHEM}-\mathrm{O}_{3}$ formation was broken down into ozone formation for each specific $\mathrm{N}$-source in a fully additive fashion. Results for the source attribution of the $\mathrm{NO}_{\mathrm{x}}$ and $\mathrm{O}_{3}$ concentrations are discussed below.

[12] Figure 3 presents the calculated percent contributions of various reactive nitrogen sources to the $\mathrm{NO}_{\mathrm{x}}$ concentration at the surface, $500 \mathrm{mbar}$ and $250 \mathrm{mbar}$, respectively. Surface $\mathrm{NO}_{x}$ emissions contribute predominantly to the $\mathrm{NO}_{\mathrm{x}}$ at ground levels in most of China, especially in polluted areas where more than $90 \%$ of $\mathrm{NO}_{\mathrm{x}}$ are attributed to the surface source. In remote areas of the Tibetan plateau, the contributions to surface $\mathrm{NO}_{x}$ concentrations from (western) LBI and, to a lesser extent, from the lightning source are considerable. At $500 \mathrm{mbar}$, the contribution from surface emissions is still dominant over eastern China (more than 50\%), while the lightning source is significant in some tropical parts and STE becomes more important over northern areas. At 250 mbar, surface emissions contribute to $\mathrm{NO}_{\mathrm{x}}$ concentrations still significantly in the downstream of polluted areas (approximately $30-50 \%$ ). The lightning contributes dominantly over the Tibetan plateau and its south in the tropics, and STE does over northern areas. The contribution of LBI is limited to some southeastern and western areas. It is noted that at this altitude, where maximum aircraft emissions occur, the contribution of aviation to the $\mathrm{NO}_{\mathrm{x}}$ is considerable $(20-$ $30 \%$ ) in the flight corridors as well as downstream regions over southeastern China. However, the signature of aviation $\mathrm{NO}_{\mathrm{x}}$ is not so significant at 250 mbar over the northern China close to Beijing, where the "background" $\mathrm{NO}_{\mathrm{x}}$ is high mainly due to surface emissions. By "tagging" the fossil fuel $\mathrm{NO}_{\mathrm{x}}$ emitted by China in a global model simulation, Horowitz and Jacob [1999] estimated that at higher altitudes over southern and eastern China, the contribution of emissions from China is $10-40 \%$ of the total. In the latitude range $0-40^{\circ} \mathrm{N}$, emissions from China account for $10-20 \%$ of the $\mathrm{NO}_{\mathrm{x}}$ present over the western North Pacific through most of the depth of the troposphere. Our results are generally in agreement with those of Horowitz and Jacob [1999].

[13] Figure 4 presents the calculated percent contributions of the $\mathrm{O}_{3}$ tracers produced via the individual $\mathrm{NO}_{\mathrm{x}}$ tracers from various sources (surface, aviation, lightning, STE and LBI) to the $\mathrm{O}_{3}$ concentration at the surface, $500 \mathrm{mbar}$ and 250 mbar, respectively. The $\mathrm{O}_{3}$ produced via surface-emitted $\mathrm{NO}_{\mathrm{x}}$ is the dominant contributor to the $\mathrm{O}_{3}$ in the polluted boundary layer, while the contributions via all other $\mathrm{NO}_{\mathrm{x}}$ sources are relatively small. At higher altitudes over and downstream of these polluted areas, the contribution of the $\mathrm{O}_{3}$ produced via surface-emitted $\mathrm{NO}_{\mathrm{x}}$ is still highest among other $\mathrm{NO}_{\mathrm{x}}$ sources, accounting up to $20 \%$ and $10 \%$ of the total $\mathrm{O}_{3}$ concentrations in the middle and upper troposphere, respectively. The $\mathrm{O}_{3}$ produced via lateral imported $\mathrm{NO}_{\mathrm{x}}$ provides an important chemical contribution to the $\mathrm{O}_{3}$ in the free troposphere. The contributions of the $\mathrm{NO}_{\mathrm{x}}$ sources from lightning and STE are still considerable in some regions of the free troposphere. It is noted that the maximum contribution to the $\mathrm{O}_{3}$ from a source of $\mathrm{NO}_{\mathrm{x}}$ may not coincide with the maximum contribution to the $\mathrm{NO}_{\mathrm{x}}$ from this source (Figure 3). For instance, the STE $\mathrm{NO}_{\mathrm{x}}$ contributes predominantly to the $\mathrm{NO}_{\mathrm{x}}$ in the upper troposphere over northern areas, while the contribution of the $\mathrm{O}_{3}$ produced via the STE $\mathrm{NO}_{x}$ is negligent, since $\mathrm{O}_{3}$ in these regions are dynamically controlled (Figure 1). The contribution of the $\mathrm{O}_{3}$ produced via aircraft emitted $\mathrm{NO}_{\mathrm{x}}$ is relatively small, about $2 \%$ at the cruise altitude downstream of main flight routes. The maximum concentration of $\mathrm{O}_{3}$ produced via aircraft emitted $\mathrm{NO}_{\mathrm{x}}$ is nearly $1 \mathrm{ppbv}$ over southeastern China (not shown). The concentration of $\mathrm{O}_{3}$ 

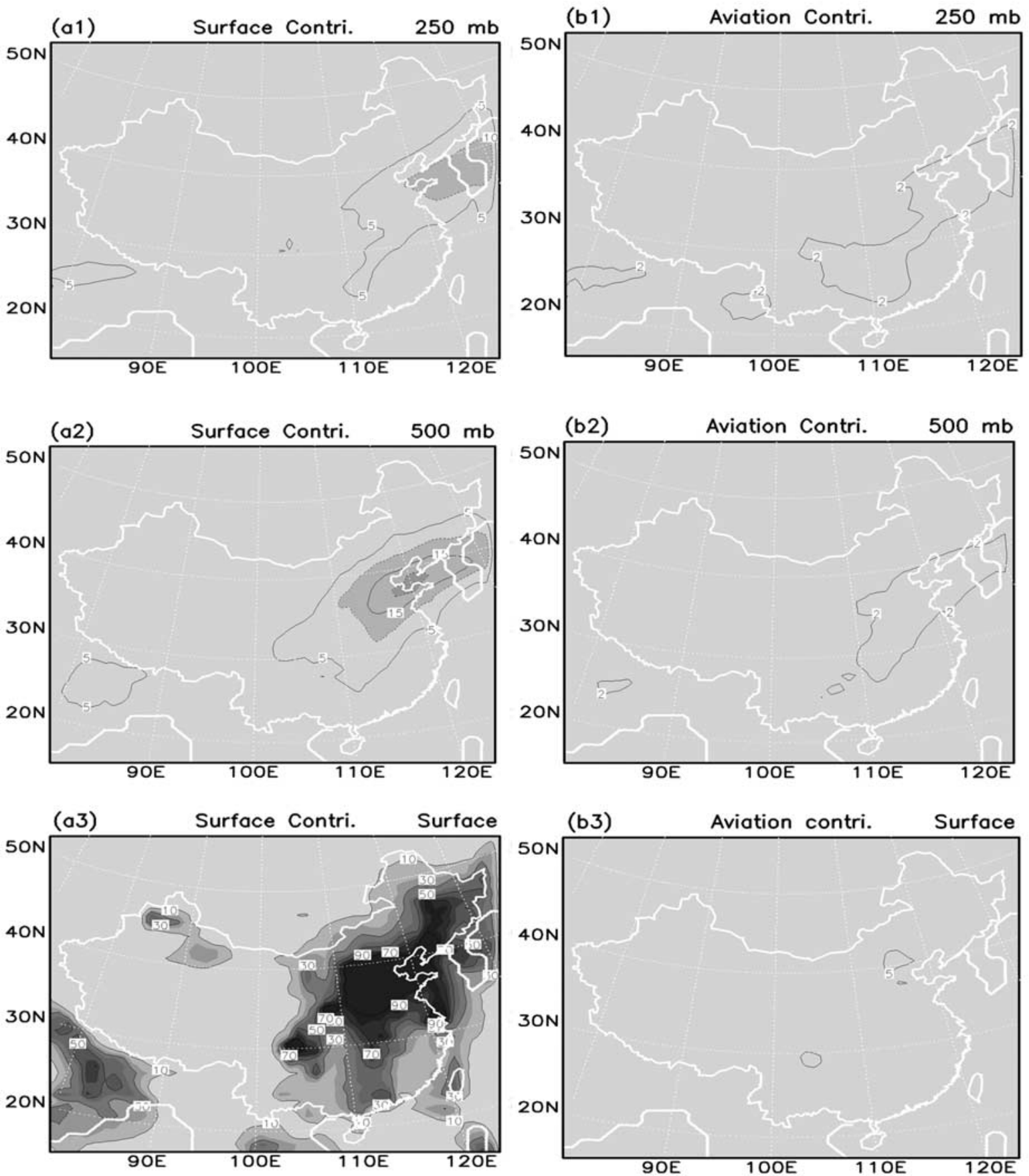

Figure 4. Calculated percent contributions to $\mathrm{O}_{3}$ concentrations at the surface (1), $500 \mathrm{mbar}$ (2) and 250 mbar (3) from $\mathrm{O}_{3}$ tracers formed via various reactive nitrogen sources including surface emission (a), aviation (b), lightning (c), stratospheric intrusion (d), and lateral import (e) for July 10-15, 1995. Different contour intervals are used, with 5 for panels a1-a2 and b3-e3, 20 for panel a3, 1 for panels b1b2, and 2 for panels c1-e1 and c2-e2.

produced via surface-emitted $\mathrm{NO}_{\mathrm{x}}$ is calculated to reach its highest values of approximately $10 \mathrm{ppbv}$ in the middle troposphere and $5 \mathrm{ppbv}$ in the upper troposphere.

\section{Regional Ozone Budget}

[14] Table 1 presents the calculated daily-averaged tropospheric $\mathrm{O}_{3}$ budget over China for July $10-15,1995$. Tropo- spheric $\mathrm{O}_{3}$ over China is simulated to come mainly from two large sources: transport from the western boundary $\left(1412 \mathrm{Gg} \mathrm{d}^{-1}\right)$ and photochemical formation via $\mathrm{NO}_{\mathrm{x}}$ $\left(947 \mathrm{Gg} \mathrm{d}^{-1}\right)$ within the region. The other two sources are transport from the southern boundary $\left(293 \mathrm{Gg} \mathrm{d}^{-1}\right)$ and STE $\left(87 \mathrm{Gg} \mathrm{d}^{-1}\right)$. Tropospheric $\mathrm{O}_{3}$ over China is simulated to lose mainly by two quantitatively comparable sinks: photochemical destruction within the region $\left(1186 \mathrm{Gg} \mathrm{d}^{-1}\right)$ and 

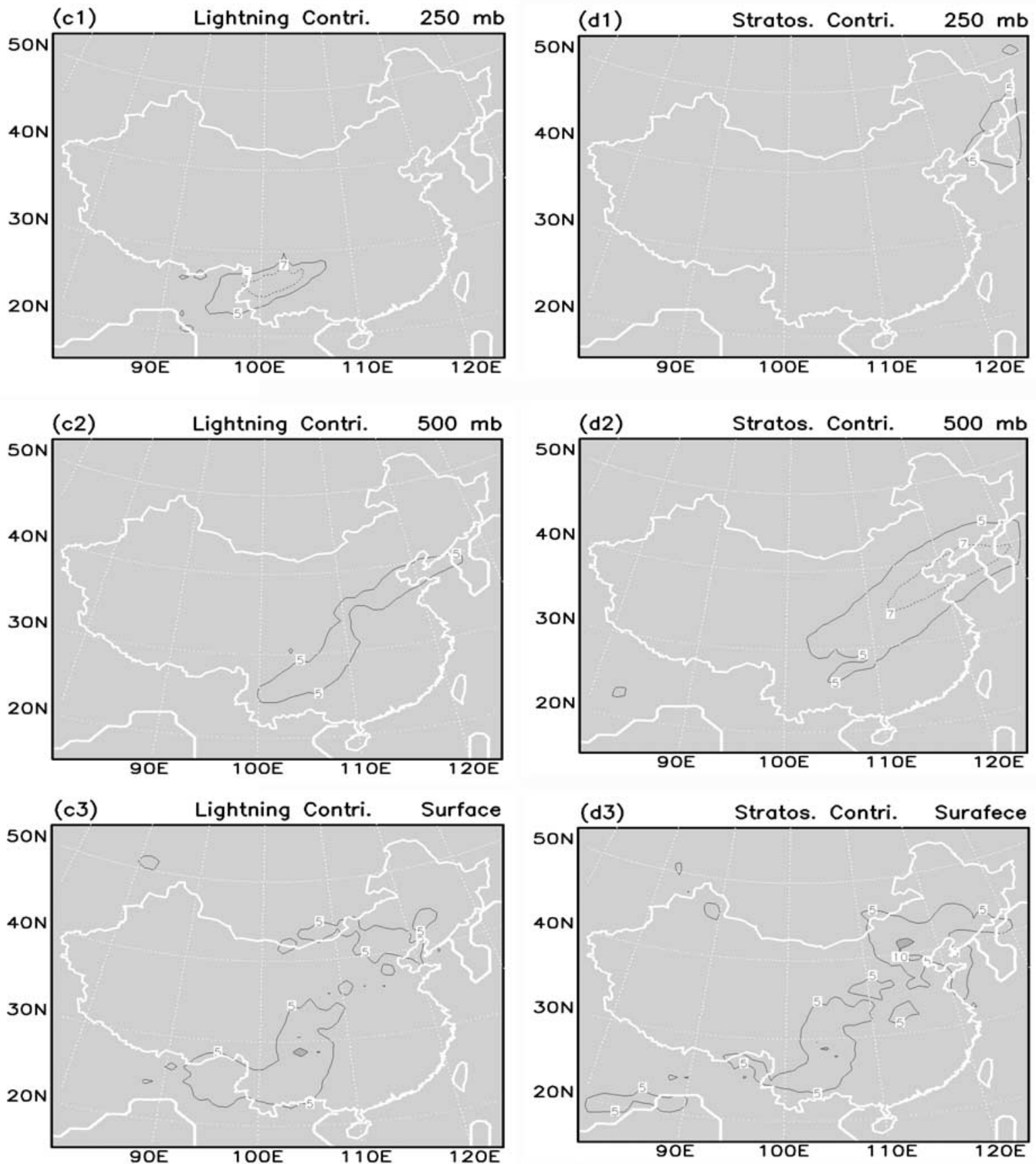

Figure 4. (continued)

transport to the eastern boundary $\left(899 \mathrm{Gg} \mathrm{d}^{-1}\right)$. The other two sinks are deposition on surface $\left(237 \mathrm{Gg} \mathrm{d}^{-1}\right)$ and transport to the northern boundary $\left(55 \mathrm{Gg} \mathrm{d}^{-1}\right)$. Photochemical destruction of $\mathrm{O}_{3}$ is larger than its photochemical formation, leading to a net destruction of $\mathrm{O}_{3}\left(238 \mathrm{Gg} \mathrm{d}^{-1}\right)$ in the troposphere of the region. There is an imbalance $\left(751 \mathrm{Gg} \mathrm{d}^{-1}\right)$ between the amounts of $\mathrm{O}_{3}$ transported into and out of the region in the horizontal, with the former being much larger than the latter. This imbalance in $\mathrm{O}_{3}$ transport for the region is due to the convergence of air masses over the region [see, Ma et al., $2002 \mathrm{~b}$, Figure 1]. In addition, water vapor is high during this period, and hence $\mathrm{O}_{3}$ is net destroyed over the region. We did two sensitivity runs: one with a $20 \%$ reduction in the western boundary concentration of $\mathrm{O}_{3}$, the other with a $20 \%$ reduction in the mixing ratio of water vapor over the region. The photochemical formation and destruction of $\mathrm{O}_{3}$ changes by factors of 1.07 and 0.86 in the former case, and by factors of 1.00 and 0.48 in the latter case, respectively. As a result, the net $\mathrm{O}_{3}$ production changes to $-6 \mathrm{Gg} \mathrm{d}^{-1}$ with a $20 \%$ reduction in the western boundary concentration of $\mathrm{O}_{3}$, and to $378 \mathrm{Gg} \mathrm{d}^{-1}$ with a $20 \%$ reduction in the mixing ratio of water vapor over the region. The importance of water vapor in the photochemical budget of $\mathrm{O}_{3}$ was also revealed in the study of Ma et al. [2002a] for the Waliguan station. The 

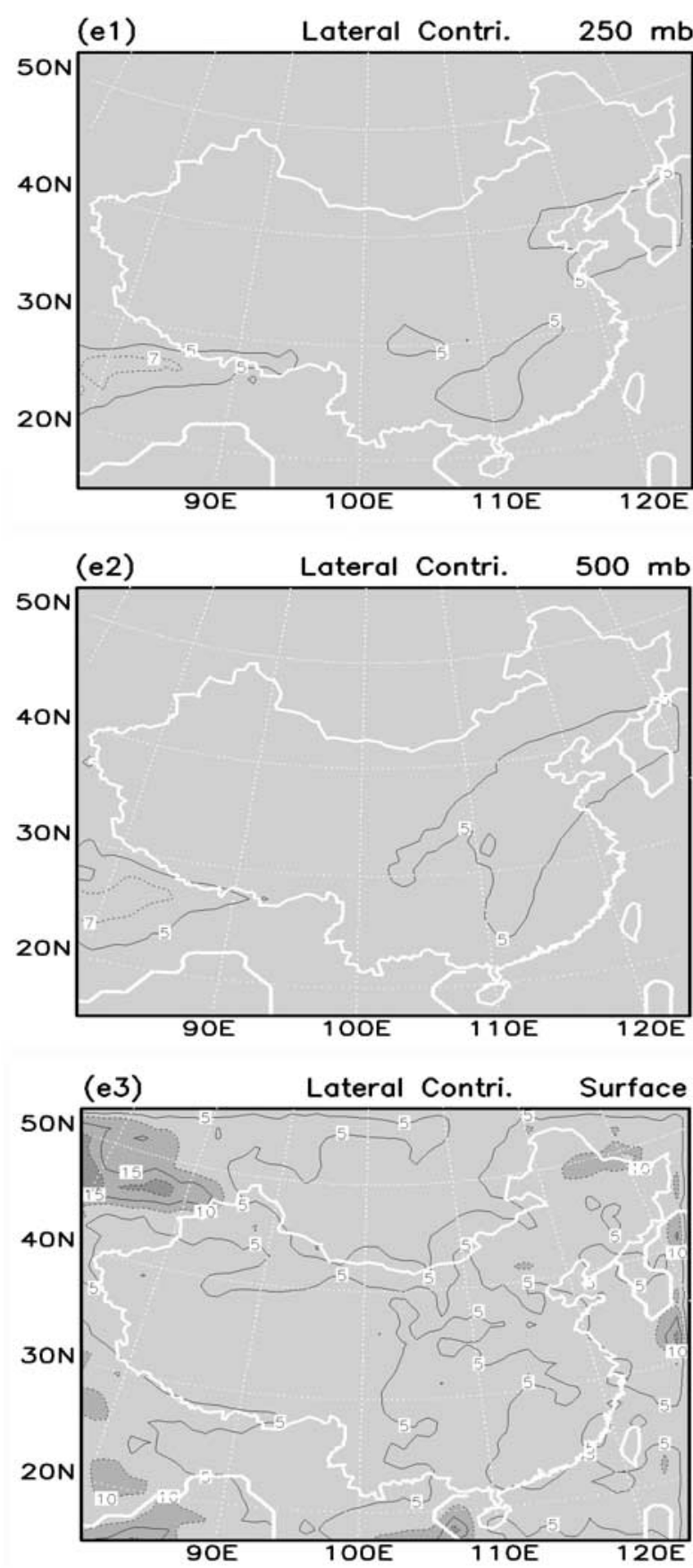

Figure 4. (continued)

amount of transported $\mathrm{O}_{3}$ at the northern boundary and at the tropopause varies significantly from day to day, and in some cases can change the sign, i.e., to different directions. This may affect the regional $\mathrm{O}_{3}$ budget greatly. On the other hand, day-to-day variations in formation, destruction and deposition of $\mathrm{O}_{3}$ are quite small, with only a few percent. The total $\mathrm{O}_{3}$ tendency over the region is $363 \mathrm{Gg} \mathrm{d}^{-1}$, and varies day-today by as much as $\pm 140 \%$. This variability is caused mainly by the changes in the $\mathrm{O}_{3}$ flux during the simulation period, which is in turn determined by the $\mathrm{O}_{3}$ concentration and wind. While the $\mathrm{O}_{3}$ concentration is fixed in the upper boundary and varied much less in the lateral boundaries,
Table 1. Calculated Daily-Averaged Tropospheric $\mathrm{O}_{3}$ Budget Over the Model Domain for the Period July 10-15, 1995

\begin{tabular}{lr}
\hline \multicolumn{1}{c}{ Process } & Budget $^{\mathrm{a}}, \mathrm{Gg} \mathrm{d}^{-1}$ \\
\hline Stratosphere-troposphere exchange $^{\mathrm{b}}$ & $87 \pm 110$ \\
Net lateral boundary transport ${ }^{\mathrm{b}}$ & $751 \pm 445$ \\
North & $-55 \pm 520$ \\
East & $-899 \pm 241$ \\
South & $293 \pm 162$ \\
West & $1412 \pm 190$ \\
Net photochemical production ${ }^{\mathrm{c}}$ & $-238 \pm 31$ \\
Formation & $947 \pm 36$ \\
Destruction & $1186 \pm 9$ \\
Deposition on the surface & $237 \pm 10$ \\
Total Tendency & $363 \pm 514$ \\
\hline${ }^{\mathrm{a}}$ Expressed in the form of means \pm standard deviations. & \\
${ }^{\mathrm{b}}$ Positive sign means transport in, and negative sign transport out. \\
${ }^{\mathrm{c}}$ Positive sign means net production, and negative sign net destruction. \\
${ }^{\mathrm{d}}$ Sum of stratosphere-troposphere exchange, net lateral boundary trans- \\
port, net photochemical production, and deposition on the surface.
\end{tabular}

the wind in the boundaries may fluctuate significantly and sometimes change to the opposite direction, leading to dayto-day variations in the amount of $\mathrm{O}_{3}$ transported into and out of the region. However, due to the large model domain used, the total $\mathrm{O}_{3}$ tendency only accounts for $2-3 \%$ of the total $\mathrm{O}_{3}$ burden $(13758 \mathrm{Gg})$ in the troposphere over the region.

[15] Table 2 shows the calculated daily-averaged photochemical budget for $\mathrm{O}_{3}$ formed in the troposphere over China via various $\mathrm{NO}_{\mathrm{x}}$ sources for July 10-15, 1995. Surface $\mathrm{NO}_{\mathrm{x}}$ emissions are the most important photochemical source of $\mathrm{O}_{3}$ in the boundary layer (BL) of the region $\left(171 \mathrm{Gg} \mathrm{d}^{-1}\right)$, accounting for half of the total $\mathrm{O}_{3}$ formation in this region. In addition, LBI-originated $\mathrm{NO}_{\mathrm{x}}$ contributes $40 \%$ of the photochemical source of $\mathrm{O}_{3}$ in $\mathrm{BL}$ of the region $\left(136 \mathrm{Gg} \mathrm{d}^{-1}\right)$. In the free troposphere $(\mathrm{FT})$, photochemical $\mathrm{O}_{3}$ formation via the LBI-originated $\mathrm{NO}_{\mathrm{x}}$ (predominantly from the western and southern boundaries) is significant $\left(375 \mathrm{Gg} \mathrm{d}^{-1}\right)$, which contributes about $60 \%$ of the total $\mathrm{O}_{3}$ formation in FT. The contribution of the STE-originated $\mathrm{NO}_{\mathrm{x}}$ to the total $\mathrm{O}_{3}$ formation in FT is also considerable $\left(103 \mathrm{Gg} \mathrm{d}^{-1}\right)$ with a value of nearly $20 \%$. The contributions from surface, aviation and lightning $\mathrm{NO}_{\mathrm{x}}$ sources to the $\mathrm{O}_{3}$ photochemical formation in FT are comparable, each less than $10 \%$. The total destruction of $\mathrm{O}_{3}$ that are formed via the $\mathrm{NO}_{\mathrm{x}}$-controlled photochemistry $\left(100+86=186 \mathrm{Gg} \mathrm{d}^{-1}\right)$ is much smaller than the $\mathrm{O}_{3}$ destruction given in Table 1

Table 2. Calculated Photochemical Budget and Deposition for Tropospheric $\mathrm{O}_{3}$ Formed via Various $\mathrm{NO}_{\mathrm{x}}$ Sources over the Model Domain for the Period July $10-15,1995^{\mathrm{a}}$

\begin{tabular}{|c|c|c|c|c|c|c|c|}
\hline \multirow[b]{2}{*}{ Source } & \multicolumn{2}{|c|}{ Formation } & \multicolumn{2}{|c|}{$\underline{\text { Destruction }}$} & \multicolumn{2}{|c|}{$\begin{array}{c}\text { Net } \\
\text { Production }\end{array}$} & \multirow[b]{2}{*}{ Deposition } \\
\hline & FT & BL & FT & $\mathrm{BL}$ & FT & $\mathrm{BL}$ & \\
\hline Surface & 53 & 171 & 20 & 39 & 33 & 132 & 38 \\
\hline Aviation & 23 & 5 & 8 & 4 & 15 & 1 & 4 \\
\hline Lightning & 55 & 16 & 14 & 8 & 41 & 8 & 8 \\
\hline STE & 103 & 11 & 20 & 10 & 83 & 1 & 8 \\
\hline LBI & 375 & 136 & 38 & 25 & 337 & 111 & 15 \\
\hline Total & 609 & 339 & 100 & 86 & 509 & 253 & 73 \\
\hline
\end{tabular}

${ }^{\mathrm{a}}$ Units are $\mathrm{Gg}$ /day. FT refers to the free troposphere and BL the boundary layer. 
$\left(1186 \mathrm{Gg} \mathrm{d}^{-1}\right)$. The deficit $\left(1186-186=1000 \mathrm{Gg} \mathrm{d}^{-1}\right)$ is attributed to the destruction part of the $\mathrm{O}_{3}$ that has been transported from outside due to STE and LBI. The deposition part of those transported $\mathrm{O}_{3}$ can also be estimated (237 $\left.-73=164 \mathrm{Gg} \mathrm{d}^{-1}\right)$. The net BL production of $\mathrm{O}_{3}$ from LBI $\mathrm{NO}_{\mathrm{x}}$ sources $\left(111 \mathrm{Gg} \mathrm{d}^{-1}\right)$ is very similar in magnitude to the one from surface $\mathrm{NO}_{\mathrm{x}}$ sources $\left(132 \mathrm{Gg} \mathrm{d}^{-1}\right)$. Moreover, the net $\mathrm{FT}$ production of $\mathrm{O}_{3}$ from LBI $\mathrm{NO}_{\mathrm{x}}$ sources $(337 \mathrm{Gg}$ $\left.\mathrm{d}^{-1}\right)$ is 10 times larger than that from surface $\mathrm{NO}_{\mathrm{x}}$ sources $\left(33 \mathrm{Gg} \mathrm{d}^{-1}\right)$. On the other hand, Figure 4 (panels a1-a3 and $\mathrm{e} 1-\mathrm{e} 3$ ) shows that the contribution of $\mathrm{O}_{3}$ concentration associated with surface $\mathrm{NO}_{\mathrm{x}}$ sources predominates over that associated with LBI $\mathrm{NO}_{\mathrm{x}}$ sources in both BL and FT. This is partly due to the fact that $\mathrm{O}_{3}$ from $\mathrm{LBI} \mathrm{NO}_{\mathrm{x}}$ sources is mostly formed in the regions where the $\mathrm{O}_{3}$ concentration is large [see $M a$ et al., 2002b, Figure 11 (panels a1-a3)] but not controlled by in situ photochemistry within the domain (Figure 1). It is also partly due to the fact that $\mathrm{O}_{3}$ formed from $\mathrm{LBI} \mathrm{NO}_{\mathrm{x}}$ sources is spread out more uniformly over the model domain. It is implicated that while the photochemical production of $\mathrm{O}_{3}$ due to long-range transport of $\mathrm{O}_{3}$ precursors is significant in the regional and global scales, its verification by field experiments will be difficult, as its signals have become too weak due to smoothing.

\section{Conclusions}

[16] We have investigated, by using a tagging procedure in the model simulation, the contributions of various sources to the $\mathrm{NO}_{\mathrm{x}}$ and $\mathrm{O}_{3}$ concentrations in the troposphere over China, and estimated the regional $\mathrm{O}_{3}$ budget for the summertime period. We have traced $\mathrm{O}_{3}$ originating from stratosphere-troposphere exchange (STE), lateral boundary import (LBI), and formation by in situ photochemistry via NO. Furthermore, we have also traced nitrogen species from surface emission, aviation, lightning, STE and LBI, as well as $\mathrm{O}_{3}$ formed by chemical reactions via the corresponding NO from these sources.

[17] The contribution of photochemistry occurring with the region is shown to be a dominant source of $\mathrm{O}_{3}$ in the polluted boundary layer (BL) of eastern China and, in the free troposphere (FT), it still contributes $20-40 \%$ of the $\mathrm{O}_{3}$ concentration in downstream regions of polluted sources. Surface emissions are the dominant contributor to $\mathrm{NO}_{\mathrm{x}}$ and hence $\mathrm{O}_{3}$ concentrations in the polluted $\mathrm{BL}$, while at higher altitudes the $\mathrm{O}_{3}$ produced via surface-emitted $\mathrm{NO}_{x}$ accounts for $10-20 \%$ of the total $\mathrm{O}_{3}$ concentrations over these polluted regions. In the upper troposphere, the $\mathrm{O}_{3}$ produced via surface-emitted $\mathrm{NO}_{\mathrm{x}}$ is simulated to reach its highest values of about 5 ppbv over the polluted region. The contribution of aviation to $\mathrm{NO}_{x}$ and $\mathrm{O}_{3}$ concentrations is found to be small relatively even at its cruise altitudes, where the absolute $\mathrm{O}_{3}$ produced via aircraft emitted $\mathrm{NO}_{x}$ is simulated nearly to $1 \mathrm{ppbv}$ in the flight corridors and down stream regions.

[18] STE is simulated to contribute considerably to the $\mathrm{O}_{3}$ concentration in the upper troposphere, especially over northern parts of the region where STE is very active. Even down to the surface, the $\mathrm{O}_{3}$ from STE contributes 30-40\% of the $\mathrm{O}_{3}$ concentration on the Tibetan Plateau. However, the contribution of the $\mathrm{O}_{3}$ produced via $\mathrm{NO}_{x}$ from STE to tropospheric $\mathrm{O}_{3}$ over the region is much small relatively, since photochemistry is not so active in those regions. For the same reason, the contribution of the $\mathrm{O}_{3}$ produced via lightning $\mathrm{NO}_{\mathrm{x}}$ to tropospheric $\mathrm{O}_{3}$ is also limited over the region during the investigated period. We have found that LBI contributes predominantly to tropospheric $\mathrm{O}_{3}$ in most regions, except for the polluted $\mathrm{BL}$ of eastern China and the upper troposphere of northeastern region. This contribution comes mainly from import of $\mathrm{O}_{3}$ itself and, to a smaller extent, from in situ photochemistry via imported $\mathrm{NO}_{\mathrm{x}}$.

[19] Our regional budget analysis indicates that an imbalance between $\mathrm{O}_{3}$ transported in and out of the region exits, due to the convergence of air masses during the simulation period. The photochemistry in the troposphere over the region acts as a sink for $\mathrm{O}_{3}$ during the simulated period. Our sensitivity studies show that water vapor is an important factor that influences the photochemical budget of $\mathrm{O}_{3}$ over the region. Photochemical formation of $\mathrm{O}_{3}$ in $\mathrm{BL}$ is predominantly via surface-emitted $\mathrm{NO}_{\mathrm{x}}$, and $\mathrm{O}_{3}$ formation in FT is predominantly via LBI-originated $\mathrm{NO}_{\mathrm{x}}$. The net FT production of $\mathrm{O}_{3}$ from LBI $\mathrm{NO}_{x}$ sources is calculated to be 10 times larger than that from surface $\mathrm{NO}_{\mathrm{x}}$ sources. However, its signals are weaker according to our tracer-tagging simulations, since $\mathrm{O}_{3}$ formed from LBI $\mathrm{NO}_{\mathrm{x}}$ sources is spread out more uniformly over the model domain. $\mathrm{O}_{3}$ formation in $\mathrm{BL}$ via surface-emitted $\mathrm{NO}_{\mathrm{x}}\left(171 \mathrm{Gg} \mathrm{d}^{-1}\right)$ cannot completely be balanced by chemical destruction (39 $\left.\mathrm{Gg} \mathrm{d}^{-1}\right)$ and deposition $\left(38 \mathrm{Gg} \mathrm{d}^{-1}\right)$ in BL. This implies that more than half of produced $\mathrm{O}_{3}$ (up to $94 \mathrm{Gg} \mathrm{d}^{-1}$ ) can be transported out of BL of the region.

[20] Acknowledgments. This work was supported by the Natural Science Foundation of China (NSFC) under the project 49805008. We would like to thank the two anonymous reviewers for their helpful comments on the manuscript.

\section{References}

Horowitz, L. W., and D. J. Jacob, Global impact of fossil fuel combustion on atmospheric $\mathrm{NO}_{\mathrm{x}}$, J. Geophys. Res., 104, 23,823-23,840, 1999.

Kentarchos, A. S., G. J. Roelofs, and J. Lelieveld, Model study of a stratospheric intrusion event at lower midlatitudes associated with the development of a cutoff low, J. Geophys. Res., 104, 1717-1727, 1999.

Lamarque, J.-F., G. P. Brasseur, P. G. Hess, and J. F. Müller, Threedimensional model study of the relative contributions of the different nitrogen sources in the troposphere, J. Geophys. Res., 101, 22,955$22,968,1996$

Lelieveld, J., and F. J. Dentener, What controls tropospheric ozone?, J. Geophys. Res., 105, 3531-3551, 2000.

Ma, J., J. Tang, X. J. Zhou, and X. S. Zhang, Estimates of the chemical budget for ozone at Waliguan Observatory, J. Atmos. Chem., 41, 21-48, $2002 a$.

Ma, J., H. Liu, and D. Hauglustaine, Summertime tropospheric ozone over China simulated with a regional chemical transport model, 1. Model description and evaluation, J. Geophys. Res, 107, doi:10.1029/ 2001JD001354, in press, 2002b.

Roelofs, G.-J., and J. Lelieveld, Model study of the influence of crosstropopause $\mathrm{O}_{3}$ transport on tropospheric $\mathrm{O}_{3}$ levels, Tellus, Ser. B, 49, $38-55,1997$.

Wang, Y., J. A. Logan, and D. J. Jacob, Global simulation of tropospheric $\mathrm{O}_{3}-\mathrm{NO}_{\mathrm{x}}$-hydrocarbon chemistry, 2, Model evaluation and global ozone budget, J. Geophys. Res., 103, 10,727-10,755, 1998.

D. Hauglustaine, Laboratoire des Sciences du Climate et de l'Environnement, Laboratoire Mixte CEA-CNRS, Orme des Merisiers, 91191 Gif-surYvette CEDEX, France. (hauglustaine@cea.fr)

J. Ma and X. Zhou, Chinese Academy of Meteorological Sciences, Beijing 100081, People's Republic of China. (maj@public.bta.net.cn) 